\title{
Halobacillus faecis sp. nov., a spore-forming bacterium isolated from a mangrove area on Ishigaki Island, Japan
}

\author{
Correspondence \\ Sun-Young An \\ an12su@hotmail.com
}

\author{
Sun-Young An, ${ }^{1}$ Kaneo Kanoh, ${ }^{2}$ Hiroaki Kasai, ${ }^{2}$ Keiichi Goto ${ }^{3}$ \\ and Akira Yokota ${ }^{1}$ \\ ${ }^{1}$ Institute of Molecular and Cellular Biosciences, University of Tokyo, Yayoi, 1-1-1 \\ Bunkyo-Ku, Tokyo 113-0032, Japan \\ ${ }^{2}$ Marine Biotechnology Co. Ltd, 3-75-1 Heita, Kamaishi, Iwate 026-0001, Japan \\ ${ }^{3}$ Microbiological and Analytical Group, Food Research Laboratories, Mitsui Norin Co. Ltd, \\ 223-1 Miyahara, Fujieda, Shizuoka 426-0133, Japan
}

The genus Halobacillus was first described by Spring et al. in 1996 and, at the time of writing, comprised nine recognized species: Halobacillus halophilus, Halobacillus litoralis and Halobacillus trueperi (Spring et al., 1996), Halobacillus salinus (Yoon et al., 2003), Halobacillus karajensis (Amoozegar et al., 2003), Halobacillus locisalis (Yoon et al., 2004), Halobacillus dabanensis and Halobacillus aidingensis (Liu et al., 2005) and Halobacillus yeomjeoni (Yoon et al., 2005). Members of the genus Halobacillus have a cell-wall peptidoglycan type based on LOrn-D-Asp, which clearly differentiates them from other related genera. In this study, we report a strain, IGA7-4 $4^{\mathrm{T}}$, isolated from a mangrove area (Ishigaki Island, Japan) in the course of environmental investigation. On the basis of phenotypic characteristics, chemotaxonomic data and phylogenetic analysis of the 16S rRNA gene sequence, the isolate represents a novel species of Halobacillus.

Strain IGA7-4 $4^{\mathrm{T}}$ was isolated from sediment collected from a mangrove area of the estuary of the Nagura River in Ishigaki Island, Okinawa, Japan in 2004. Orange-coloured

The GenBank/EMBL/DDBJ accession number for the 16S rRNA gene sequence of strain IGA7-4 ${ }^{\top}$ is $A B 243865$. colonies appeared after incubation for 1 week at $25{ }^{\circ} \mathrm{C}$ on 1/10-diluted marine agar [3.74 g Difco marine broth 2216 (BD), $750 \mathrm{ml}$ filtered seawater, $250 \mathrm{ml}$ distilled water and $15 \mathrm{~g}$ agar]. Isolate IGA7 $-4^{\mathrm{T}}$ was routinely cultivated on marine agar at $30{ }^{\circ} \mathrm{C}$. Cell morphology and motility were examined by using phase-contrast microscopy (BX60 microscope; Olympus). Growth under anaerobic conditions was determined after incubation for 1 week in an AnaeroPack (Mitsubishi Gas Chemical Co., Inc.). Catalase activity was tested by adding a drop of $3 \% \mathrm{H}_{2} \mathrm{O}_{2}$ to a single colony and was recorded as positive when development of bubbles was observed. Oxidase activity was determined by using cytochrome oxidase paper (Nissui Pharmaceutical Co., Ltd). API 20E, API $50 \mathrm{CH}$ and API ZYM microtest galleries (bioMérieux) were used to determine physiological and biochemical characteristics. The API 20E and API 50 $\mathrm{CH}$ strips were incubated for $48 \mathrm{~h}$ at $37{ }^{\circ} \mathrm{C}$ and the API ZYM strip was recorded after incubation for $4 \mathrm{~h}$ at $30{ }^{\circ} \mathrm{C}$.

The isolate was Gram-positive, strictly aerobic, non-motile and rod-shaped. The morphological and physiological characteristics are provided in the species description. The isolate showed differences from other species of Halobacillus in some physiological properties (Table 1). 
Table 1. Differential characteristics of Halobacillus species

Taxa: 1, strain IGA7-4 ${ }^{\mathrm{T}}$ (H. faecis sp. nov.); 2. H. litoralis (data from Spring et al., 1996); 3, H. halophilus (Claus et al., 1983; Spring et al., 1996); 4, H. trueperi (Spring et al., 1996); 5, H. salinus (Yoon et al., 2003); 6, H. karajensis (Amoozegar et al., 2003); 7, H. locisalis (Yoon et al., 2004); 8, H. dabanensis (Liu et al., 2005); 9, H. aidingensis (Liu et al., 2005); 10, H. yeomjeoni (Yoon et al., 2005). +, Positive; -, negative; W, weak reaction; ND, not determined.

\begin{tabular}{|c|c|c|c|c|c|c|c|c|c|c|}
\hline Characteristic & 1 & 2 & 3 & 4 & 5 & 6 & 7 & 8 & 9 & 10 \\
\hline Cell morphology & Rods & Rods & Cocci or oval & Rods & Rods & Rods & Rods & Rods & Rods & $\begin{array}{c}\text { Rods or long } \\
\text { filamentous } \\
\text { rods }\end{array}$ \\
\hline Motility & - & + & + & + & + & - & + & + & + & + \\
\hline Spore shape ${ }^{\star}$ & $\mathrm{E}, \mathrm{S}$ & E, $S$ & S & $\mathrm{E}, \mathrm{S}$ & $\mathrm{E}$ & E, $S$ & $\mathrm{E}$ & E & E & $\mathrm{E}$ \\
\hline $\begin{array}{l}\text { Temperature } \\
\text { range for growth } \\
\left({ }^{\circ} \mathrm{C}\right)\end{array}$ & $15-45$ & $15-43$ & $10-40$ & $10-44$ & $10-45$ & $10-49$ & $10-42$ & $15-50$ & $15-40$ & $15-48$ \\
\hline \multicolumn{11}{|l|}{$\begin{array}{l}\text { Acid production } \\
\text { from: }\end{array}$} \\
\hline D-Fructose & + & + & - & + & + & + & + & + & + & - \\
\hline D-Galactose & + & - & - & + & $\mathrm{W}$ & - & - & - & - & - \\
\hline Maltose & + & + & - & + & + & + & - & + & + & + \\
\hline Sucrose & + & + & - & + & + & - & + & + & + & + \\
\hline D-Xylose & - & + & - & - & - & - & - & + & - & - \\
\hline D-Glucose & + & + & - & + & + & + & + & + & + & + \\
\hline D-Mannitol & + & + & - & - & + & + & - & + & + & + \\
\hline Trehalose & + & + & - & + & + & ND & + & + & + & + \\
\hline $\begin{array}{l}\text { DNA G }+\mathrm{C} \text { con- } \\
\text { tent }(\mathrm{mol} \%)\end{array}$ & 46.5 & 42.0 & $40.1-40.9$ & 43.0 & 45.0 & 41.3 & 44.0 & 41.4 & 42.2 & 42.9 \\
\hline
\end{tabular}

${ }^{\star} \mathrm{E}$, Ellipsoidal; s, spherical.

†C, Centre; L, lateral; ST, subterminal.

Based on partial 16S rRNA gene sequence analyses (Goto et al., 2000, 2002), strain IGA7- $4^{\mathrm{T}}$ was grouped in the Halobacillus cluster. However, it was found to be distinct from previously described species of the genus. The $16 \mathrm{~S}$ rRNA gene sequence was determined using a 16S rRNA Gene kit following the protocols of the manufacturer (Applied Biosystems). The 16S rRNA gene sequence of strain IGA7-4 ${ }^{\mathrm{T}}$ was compared with sequences obtained from GenBank (National Centre for Biotechnology Information). The sequences were aligned using the CLUSTAL_X software package (Thompson et al., 1997), and the evolutionary distances and $K_{\text {nuc }}$ values (Kimura, 1980) were generated. Alignment gaps and ambiguous bases were not taken into consideration when 1416 bases of the $16 \mathrm{~S}$ rRNA gene nucleotides were compared. The phylogenetic tree was constructed using the neighbour-joining method (Saitou \& Nei, 1987). The topology of the phylogenetic tree was evaluated using the bootstrap resampling method of Felsenstein (1985), with 1000 replicates. Similarity values were calculated using MEGA3 (Kumar et al., 2004).

An almost-complete 16S rRNA gene sequence of strain IGA7- $4^{\mathrm{T}}$ was determined and subjected to comparative analysis. Strain IGA7 $-4^{\mathrm{T}}$ showed sequence similarities of 99.6-98.0\% to the type strains of Halobacillus species. On the other hand, 16S rRNA sequence similarities of less than $97.0 \%$ were obtained with species of other related genera. The phylogenetic tree indicated that strain IGA7-4 ${ }^{\mathrm{T}}$ was closely related to the genus Halobacillus (Fig. 1).

Genomic DNA was prepared according to the method of Marmur (1961). DNA-DNA hybridization was performed by the photobiotin-labelling method of Ezaki et al. (1989) using a multi-well plate reader (CytoFluoR; PerSeptive Biosystems). The level of DNA-DNA relatedness between strain IGA7- $4^{\mathrm{T}}$ and the type strains of $H$. trueperi, $H$. 




Fig. 1. Neighbour-joining phylogenetic tree based on 16S rRNA gene sequences showing the positions of strain IGA7- $4^{\top}$ and other related taxa. Numbers at nodes are percentage bootstrap values based on 1000 replications; only values greater than $70 \%$ are shown. Bar, 0.01 substitutions per nucleotide position. aidingensis, $H$. dabanensis, $H$. karajensis, $H$. litoralis, $H$. locisalis, $H$. yeomjeoni, $H$. halophilus and $H$. salinus were $46.6,39.5,17.6,14.5,14.2,12.5,11.4,10.3$ and $9.5 \%$, respectively. These levels of DNA-DNA relatedness were less than the threshold value of $70 \%$ suggested for separate species delineation by Wayne et al. (1987).

The $\mathrm{G}+\mathrm{C}$ content of the total DNA was measured by HPLC according to the method described by Mesbah et al. (1989). The DNA G $+\mathrm{C}$ content of strain IGA7-4 $4^{\mathrm{T}}$ was $46.5 \mathrm{~mol} \%$, which is slightly higher than those reported for other species of the genus Halobacillus (Table 1).

Cellular fatty acids of strain IGA7- $4^{\mathrm{T}}$ grown on marine agar for 3 days at $25{ }^{\circ} \mathrm{C}$ were prepared, separated and identified using the Microbial Identification System (MIDI, Inc.). The fatty acids $(>1 \%$ of the total fatty acids) of strain IGA7-4 ${ }^{\mathrm{T}}$ were anteiso- $\mathrm{C}_{15: 0} \quad(50.0 \%)$, anteiso- $\mathrm{C}_{17: 0}$ $(15.0 \%)$, iso- $\mathrm{C}_{15: 0}(13.8 \%)$, iso- $\mathrm{C}_{16: 0}(9.8 \%)$, iso- $\mathrm{C}_{17: 0}$ (2.9\%), iso- $\mathrm{C}_{14: 0}(2.5 \%), \mathrm{C}_{16: 0}(2.1 \%), \mathrm{C}_{16: 1} \omega 7 c$ alcohol $(1.9 \%)$ and $\mathrm{C}_{15: 0}(1.2 \%)$. This fatty acid profile is similar to those of other Halobacillus species (Yoon et al., 2003, 2004; Amoozegar et al., 2003; Liu et al., 2005; Yoon et al., 2005).

Analysis of cell-wall peptidoglycan of strain IGA7- $4^{\mathrm{T}}$ was carried out according to the methods described by Schleifer \& Kandler (1972). Strain IGA7-4 ${ }^{\mathrm{T}}$ possessed a cell-wall type of Orn-Asp. Respiratory quinone analysis of strain IGA7$4^{\mathrm{T}}$ was performed according to the method of Collins \& Jones (1981). The major isoprenoid quinone was MK-7.

On the basis of phenotypic, chemotaxonomic and phylogenetic data, we conclude that strain IGA7- $4^{\mathrm{T}}$ belongs to a novel species of the genus Halobacillus, for which the name Halobacillus faecis sp. nov. is proposed.

\section{Description of Halobacillus faecis sp. nov.}

Halobacillus faecis (fae'cis. L. gen. n. faecis of dredge, sediment, from which the organism was isolated).

Cells are Gram-positive, rods $(1.6-1.8 \times 2.4-3.4 \mu \mathrm{m})$ and non-motile. Ellipsoidal and spherical spores are formed in a central position. Colonies on marine agar are circular, convex and orange. Growth occurs at $15-45{ }^{\circ} \mathrm{C}$ and $\mathrm{pH}$ 5.5-9.0. $\mathrm{NaCl}$ is not required for growth but can be tolerated up to $15 \% \mathrm{NaCl}(\mathrm{w} / \mathrm{v})$. Tests for catalase, gelatinase and $\beta$-galactosidase activities are positive. $\mathrm{H}_{2} \mathrm{~S}$, acetoin and indole are not produced. Nitrate and nitrite are not reduced. Tests for oxidase, urease and tryptophan deaminase activities and citrate utilization are negative. Tests for arginine dihydrolase, lysine decarboxylase and ornithine decarboxylase are negative. Acid is produced from glycerol, ribose, galactose, glucose, fructose, mannitol, $N$-acetylglucosamine, aesculin, maltose, sucrose, trehalose, starch and glycogen, but not from erythritol, D-arabinose, L-arabinose, D-xylose, L-xylose, adonitol, methyl $\beta$-D-xyloside, mannose, sorbose, rhamnose, dulcitol, inositol, sorbitol, methyl $\alpha$-D-mannoside, methyl $\alpha$-Dglucoside, amygdalin, arbutin, salicin, cellobiose, lactose, melibiose, inulin, melezitose, raffinose, xylitol, gentiobiose, D-turanose, D-lyxose, D-tagatose, D-fucose, L-fucose, Darabitol, L-arabitol, gluconate, 2-ketogluconate and 5ketogluconate. In assays using the API ZYM system, alkaline phosphatase, esterase lipase (C8), acid phosphatase, naphthol-AS-BI-phosphohydralase, $\alpha$-galactosidase, $\beta$ galactosidase and $\alpha$-glucosidase are positive, but esterase (C4), lipase (C14), leucine arylamidase, valine arylamidase, cystine arylamidase, trypsin, $\alpha$-chymotrypsin, $\alpha$-galactosidase, $\beta$-glucuronidase, $\beta$-glucosidase, $N$-acetyl- $\beta$-glucosaminidase, $\alpha$-mannosidase and $\alpha$-fucosidase are negative. The cell wall contains peptidoglycan of the Orn-Asp type. The major isoprenoid quinone is $\mathrm{MK}-7$. Major cellular fatty acids are anteiso- $\mathrm{C}_{15: 0}$, anteiso- $\mathrm{C}_{17: 0}$, iso- $\mathrm{C}_{15: 0}$ and iso$\mathrm{C}_{16: 0}$. The DNA $\mathrm{G}+\mathrm{C}$ content of the type strain is $46.5 \mathrm{~mol} \%$.

The type strain, IGA7- $4^{\mathrm{T}} \quad\left(=\mathrm{MBIC} 08268^{\mathrm{T}}=\mathrm{IAM}\right.$ $15427^{\mathrm{T}}=$ KCTC $13121^{\mathrm{T}}$ ), was isolated from field soil in a mangrove area in Ishigaki Island, Japan.

\section{Acknowledgements}

This work was supported by the New Energy and Industrial Technology Development Organization (NEDO). 


\section{References}

Amoozegar, M. A., Malekzadeh, F., Malik, K. A., Schumann, P. \& Spröer, C. (2003). Halobacillus karajensis sp. nov., a novel moderate halophile. Int J Syst Evol Microbiol 53, 1059-1063.

Claus, D., Fahmy, F., Rolf, H. J. \& Tosunoglu, N. (1983). Sporosarcina halophila sp. nov., an obligate, slightly halophilic bacterium from salt marsh soils. Syst Appl Bacteriol 4, 496-506.

Collins, M. D. \& Jones, D. (1981). Distribution of isoprenoid quinone structural types in bacteria and their taxonomic implications. Microbiol Rev 45, 316-354.

Ezaki, T., Hashimoto, Y. \& Yabuuchi, E. (1989). Fluorometic deoxyribonucleic acid-deoxyribonucleic acid hybridization in microdilution wells as an alternative to membrane filter hybridization in which radioisotopes are used to determine genetic relatedness among bacterial strains. Int J Syst Bacteriol 39, 224-229.

Felsenstein, J. (1985). Confidence limits on phylogenies: an approach using the bootstrap. Evolution 39, 783-791.

Goto, K., Omura, T., Hara, Y. \& Sadaie, Y. (2000). Application of the partial 16S rDNA sequence as an index for rapid identification of species in the genus Bacillus. J Gen Appl Microbiol 46, 1-8.

Goto, K., Mochida, K. M., Asahara, M., Suzuki, M. \& Yokota, A. (2002). Application of the hypervariable region of the $16 \mathrm{~S} \mathrm{rDNA}$ sequence as an index for the rapid identification of species in the genus Alicyclobacillus. J Gen Appl Microbiol 48, 243-250.

Kimura, M. (1980). A simple method for estimating evolutionary rates of base substitutions through comparative studies of nucleotide sequences. J Mol Evol 16, 111-120.

Kumar, S., Tamura, K. \& Nei, M. (2004). MEGA3: integrated software for Molecular Evolutionary Genetics Analysis and sequence alignment. Brief Bioinform 5, 150-163.

Liu, W. Y., Zeng, J., Wang, L., Dou, Y. T. \& Yang, S. S. (2005). Halobacillus dabanensis sp. nov. and Halobacillus aidingensis sp. nov., isolated from salt lakes in Xinjiang, China. Int J Syst Evol Microbiol 55, 1991-1996.
Marmur, J. (1961). A procedure for the isolation of deoxyribonucleic acid from microorganisms. J Mol Biol 3, 208-218.

Mesbah, M., Premachandran, U. \& Whitman, W. B. (1989). Precise measurement of the $\mathrm{G}+\mathrm{C}$ content of deoxyribonucleic acid by high-performance liquid chromatography. Int J Syst Bacteriol 39, 159-167.

Saitou, N. \& Nei, M. (1987). The neighbor-joining method: a new method for reconstructing phylogenetic trees. Mol Biol Evol 4, 406-425.

Schleifer, K. H. \& Kandler, O. (1972). Peptidoglycan types of bacterial cell walls and their taxonomic implications. Bacteriol Rev 36, 407-477.

Spring, S., Ludwig, W., Marquez, M. C., Ventosa, A. \& Schleifer, K.-H. (1996). Halobacillus gen. nov., with descriptions of Halobacillus litoralis sp. nov. and Halobacillus trueperi sp. nov., and transfer of Sporosarcina halophila to Halobacillus halophilus comb. nov. Int J Syst Bacteriol 46, 492-496.

Thompson, J. D., Gibson, T. J., Plewniak, F., Jeanmougin, F. \& Higgins, D. G. (1997). The CLUSTAL_X windows interface: flexible strategies for multiple sequence alignment aided by quality analysis tools. Nucleic Acids Res 25, 4876-4882.

Wayne, L. G., Brenner, D. J., Colwell, R. R., Grimont, P. A. D., Kandler, O., Krichevsky, M. I., Moore, L. H., Moore, W. E. C., Murray, R. G. E. \& other authors (1987). International Committee on Systematic Bacteriology. Report of the ad hoc committee on reconciliation of approaches to bacterial systematics. Int J Syst Bacteriol 37, 463-464.

Yoon, J.-H., Kang, K. H. \& Park, Y.-H. (2003). Halobacillus salinus sp. nov., isolated from a salt lake on the coast of the East Sea in Korea. Int J Syst Evol Microbiol 53, 687-693.

Yoon, J. H., Kang, K. H., Oh, T. K. \& Park, Y. H. (2004). Halobacillus locisalis sp. nov., a halophilic bacterium isolated from a marine solar saltern of the Yellow Sea in Korea. Extremophiles 8, 23-28.

Yoon, J.-H., Kang, S.-J., Lee, C.-H., Oh, H. W. \& Oh, T.-K. (2005). Halobacillus yeomjeoni sp. nov., isolated from a marine solar saltern in Korea. Int J Syst Evol Microbiol 55, 2413-2417. 